\title{
EFFECT OF CHOLESTEROL SYNTHESIS INHIBITION IN NORMOCHOLESTEREMIC YOUNG MEN *
}

\author{
GEORGE L. CURRAN,† DANIEL L. AZARNOFF $\ddagger$ AND ROBERT E. BOLINGER \\ (From the Department of Gerontology, University of Kansas Medical Center, Kansas City, \\ Kansas)
}

(Submitted for publication January 5, 1959 ; accepted March 19, 1959)

Recently the concept of using specific inhibitors of endogenous cholesterol synthesis as a means of reducing the cholesterol content of the body has been reviewed (1). One such specific inhibitor is the metal vanadium. Salts of vanadium have been shown to inhibit the utilization of mevalonic acid for cholesterol biosynthesis (2), to inhibit cholesterol biosynthesis in vitro and in vivo (3), to induce mobilization of predeposited aortic cholesterol in rabbits (4) and to lessen the deposition of cholesterol in rabbits (5) and in birds (6) fed high cholesterol diets.

To extend these studies to man, the effects of vanadium on sterol balance in normocholesterolemic men under rigid dietary control were examined. The investigations reported here show that, under such conditions, inhibition of endogenous cholesterol biosynthesis with a salt of vanadium produces a lowering of serum cholesterol levels. The studies provide data which suggest that mobilization of tissue cholesterol stores also occurs.

\section{MATERIAL AND METHODS}

A. Experimental group. The subjects for the study were five normal male medical students, 23 to 26 years of age. The diets were prepared in a separate kitchen and the students ate in a private dining room. During the period of the study a daily weight record of the men showed variations of less than 3 per cent.

$B$. Diet. The diet consisted of an identical daily intake of the same items divided into three meals plus a

* This study was supported by grants from the United States Public Health Service (1947 C-3), Kansas Heart Association and the Grayce Simmons Freeman Medical Research Fund.

$\dagger$ Established Investigator of the American Heart Association during part of this study. Present address: Department of Medicine, St. Louis University School of Medicine, St. Louis, Mo.

¥United States Public Health Service Research Fellow of the National Heart Institute. Present address: Department of Pharmacology, Washington University Medical School, St. Louis, Mo. bedtime snack. The diet contained $109 \mathrm{Gm}$. of protein, $58 \mathrm{Gm}$. of fat and $321 \mathrm{Gm}$. of carbohydrate each day for a total of 2,242 calories. Two of the men, R. M. and E. W., received an additional 363 calories as bread and jelly to maintain their weight during the last three weeks of the study. All of the items in the diet with the exception of lettuce, tomatoes and bread were utilized from a single bulk lot purchased at the start of the experiment. Fat was supplied primarily from lean hamburger, butter, ice cream and bologna. Black coffee and tea were allowed as desired. One decavitamin tablet (U.S.P.) was given each day to obviate any possible change in available vitamins induced by modification of intestinal flora due to the vanadium. By careful weighing of portions and use of constant temperatures in cooking, variations in fat content were kept to a minimum. Weekly analyses of a total day's portion of food revealed variations of less than 2 per cent in fat and dietary sterol intake.

C. Experimental design. The men ate an identical diet during the entire study. After a two week control period, each man received diammonium oxy-tartratovanadate $^{1}$ (B. B., $100 \mathrm{mg}$; ; others, $125 \mathrm{mg}$.) orally in three divided doses each day for the experimental period of six weeks. During the final recovery period of three weeks the vanadium administration was discontinued.

D. Chemical methods. Serum. Fasting blood samples were obtained once each week. Cholesterol (7), phospholipid $(8,9)$, triglyceride (10), alkaline phosphatase (11) and transaminase (12) serum levels were determined. Serum cholesterol determinations were carried out on duplicate aliquots of sera.

Urine. Twenty-four hour samples were collected once each week and daily for the week after cessation of vanadium administration. Vanadium was determined by a colorimetric method (13) as well as spectrographically. ${ }^{2}$ 17-Ketosteroids and 17,21-dihydroxy-20-ketosteroids were determined at the start and end of the period of vanadium administration $(14,15)$. Routine urinalyses were performed on all collected urines.

Feces. The total fecal output was collected for a 72 hour period each week. The stools were immediately frozen, then combined, lyophilized and stored at $4^{\circ} \mathrm{C}$. The total 72 hour sample was ground and stored in vacuo over $\mathrm{P}_{2} \mathrm{O}_{5}$ while analyses were in progress. Three weighed aliquots

\footnotetext{
${ }^{1}$ Generously supplied by Dr. Frederick Heath of Merck, Sharp and Dohme.

2 These determinations were performed by Mead Johnson Company through the kind offices of Dr. Thomas Fleming.
} 
of each pooled 72 hour sample were extracted with acetoneethanol (1:1) for 48 hours at room temperature for determination of total digitonin precipitable sterols (16), digitonin precipitable, Liebermann-Burchard (L.B.) positive sterols (7) and total $3 \alpha$ and $\beta$-OH L.B. positive sterols (17). Using this extraction procedure and triplicate samples of dried, powdered feces, these sterol procedures were found to give as good recoveries of sterol as is the case when serum is analyzed. Some difficulty was experienced with nonspecific chromagens with the Abell, Levy, Brodie and Kendall procedure (17). For this reason, with both procedures utilizing the L.B. reaction, a correction for "fast acting" sterols was made by a two minute sample (18). Most of the "fast acting" sterols are precipitated by digitonin and are accounted for in the digitonin precipitable, L.B. negative sterol fraction. Digitonin precipitable, L.B. negative sterols were calculated by subtracting the digitonin precipitable, L.B. positive sterols (7) from the total digitonin precipitable sterols (16). Other weighed aliquots of feces were extracted with ethanol in a Soxhlet extractor for 24 hours and the extract analyzed for bile acid content (19). Total fat content was also determined on aliquots of the dried feces (20).

Diet. Aliquots of the total 24 hour diet, prepared by homogenization in a Waring Blendor with water, were analyzed for total fat (20) and neutral sterol $(7,16,17)$ content.

$E$. Statistics. A statistically significant difference in this paper is defined as a probability of $<0.05$ as calculated from the expression:

$$
\text { " } t "=\frac{\text { difference of the means }}{\text { standard error of the difference of the means }},
$$

where

standard error of the difference of the means

$$
=\sqrt{\frac{\Sigma \mathrm{d}^{2}}{\mathrm{~N}(\mathrm{~N}-1)}} \text {. }
$$

F. Calculations. From Figure 1 it is seen that: 1) $I=$ $-740+{ }^{A D}+$ gut sterol output; 2) $I=A F D+$ E.S. + B.A.; where ${ }^{A} \mathrm{D}=$ dietary sterol absorbed, calculated by method of Cook, Edwards and Riddell (21) (see Discussion); ${ }^{A F D}=$ amount of ${ }^{A D}$ excreted in 24 hours $=0.25{ }^{A D}$ (22); $740=$ total sterol in diet; $\mathrm{BA}=$ bile acids; $\mathrm{ES}=$ endogenous neutral sterols and $\mathrm{I}=$ total body sterol output to gut.

The total endogenous sterol output from the body per 24 hours (E.S. + B.A.) must equal the synthetic input per 24 hours plus any previously existent sterol excreted during that 24 hours; 3) E.S. + B.A. $=S+\Delta B$, where $\mathrm{S}=$ endogenous sterol synthesis, $\Delta \mathrm{B}=$ change in body sterol content $=$ body sterol content in vanadium periodbody sterol content in recovery period $=B_{V}-B_{R}(V=$ vanadium period, $R=$ recovery period). Substituting Equation 3 in 2:4) $\mathrm{I}={ }^{A F} \mathrm{D}+\mathrm{S}+\Delta \mathrm{B}$.

Again referring to Figure 1 , it is seen that a change in the body sterol must represent the sum of the changes in the serum and tissue sterols: 5) $\Delta \mathrm{B}=\Delta \mathrm{Se}+\Delta \mathrm{T}$, where $\Delta \mathrm{T}=$ change in tissue sterol content $=$ tissue sterol content in vanadium period-tissue sterol content in recovery period $=T_{V}-T_{R}$.

$\Delta \mathrm{Se}=$ change in total serum cholesterol $=$ total serum cholesterol content in vanadium period-total serum cholesterol content in recovery period $=S e_{V}-S_{R}$.

From the above equations, ${ }^{A} D_{R},{ }^{A} D_{V},{ }^{A F} D_{R},{ }^{A F} D_{V}, I_{R}$, $\mathrm{I}_{\mathrm{V}}, \Delta \mathrm{B}_{\mathrm{V}}$ and $\Delta \mathrm{T}_{\mathrm{V}}$ are calculated as shown in Addendum.

$S_{R}$ is obtained from Equation 4 by assuming that the steady state has again been reached and $\Delta B_{R}$ is zero (see Discussion).

$S_{V}$ is obtained by assuming that the ratio $I_{V} / I_{R}$ is proportional to the ratio $\mathrm{S}_{\mathrm{V}} / \mathrm{S}_{\mathrm{R}}$ (see Discussion).

All quantities are expressed as $\mathrm{mg}$. of cholesterol per day.

RESULTS

\section{Serum lipids}

The results of serum determinations for total cholesterol, free cholesterol, phospholipid and triglyceride are given in Table I. In Figure 2 the means of the weekly cholesterol determinations

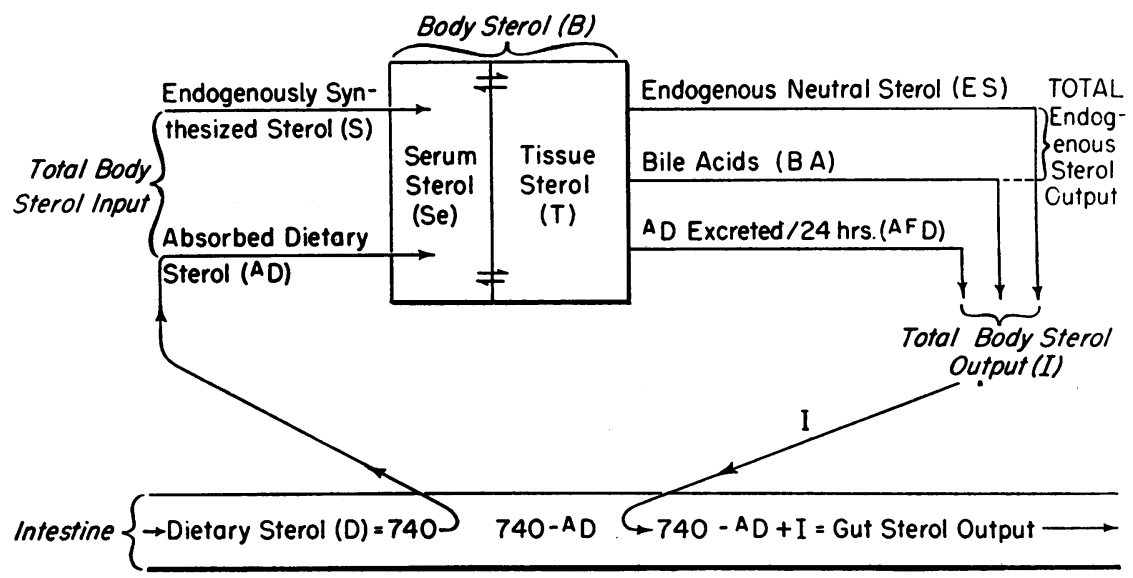

Fig. 1. Schematic Presentation of Body-Intestine Sterol Interchange 
CHOLESTEROL SYNTHESIS INHIBITION IN MAN

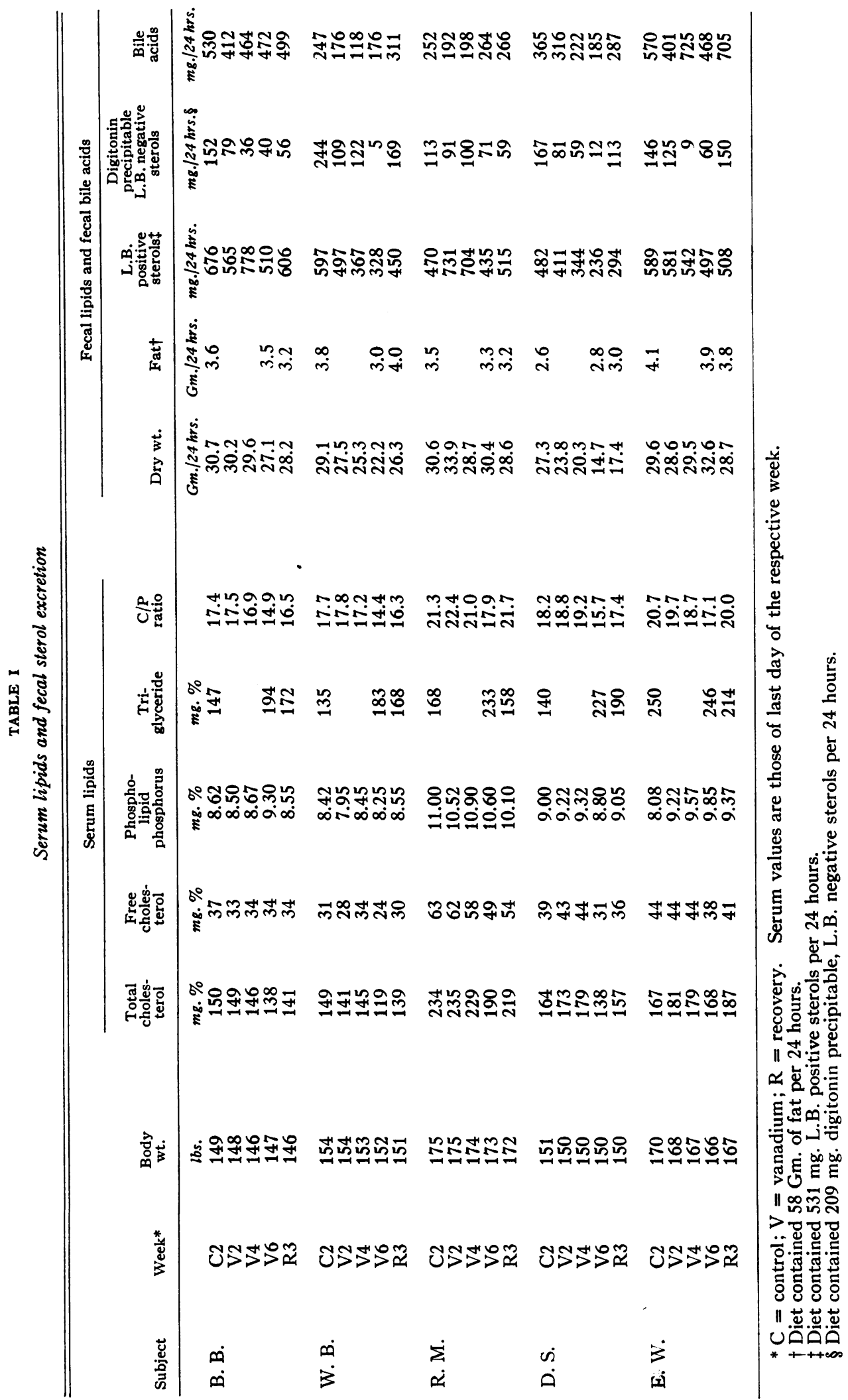




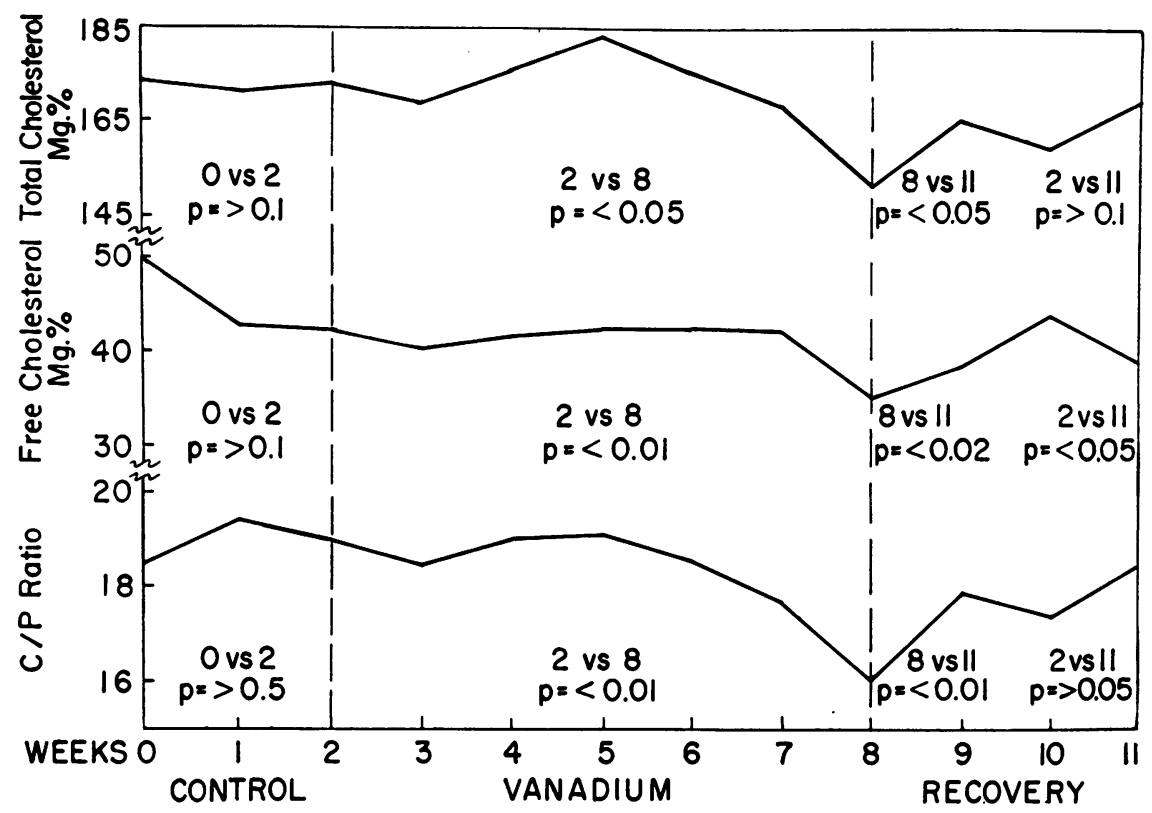

Fig. 2. Changes in Mean Serum Lipids in Normocholesteremic Males Receiving Diammonium Oxy-Tartratovanadate

Probability that given means differ significantly from each other is shown with weeks compared beneath each curve.

and the cholesterol/phospholipid phosphorus $(\mathrm{C} / \mathrm{P})$ ratio are graphed. The total cholesterol and the free cholesterol levels of the serum fell by a statistically significant amount during the six weeks of vanadium administration. The statistically more significant fall in the free serum cholesterol might be anticipated since the free serum cholesterol is a more direct indication of the rate of hepatic synthesis (23). Three weeks after cessation of vanadium administration both the total and free serum cholesterol showed a statistically significant elevation from their reduced values at Week 8 .

The serum phospholipids did not show any statistically significant trend after vanadium administration and the $\mathrm{C} / \mathrm{P}$ ratio showed a very significant decline by Week 8 and a significant increase over the Week 8 value by the end of the recovery period. If, as some investigators believe (24), the $C / P$ ratio is the most reliable indication of the atherogenicity of the serum lipids, then cholesterol synthesis inhibition has, in a period of six weeks, produced a beneficial change in this index.

It can be seen in Table I that the serum triglycerides rose during the period of vanadium administration. On statistical analysis this rise is found to be significant at $p<0.05$ and the consequent lowering after cessation of vanadium also to be significant at $p<0.05$. Whether the change in triglycerides is due to some direct action of vanadium, such as increased synthesis of triglyceride secondary to inhibition of phospholipid synthesis (25), or to a mobilization of fat resultant from the lowering of serum or liver cholesterol levels is not known at this time.

\section{Fecal sterols and bile acids}

In Table $I$ the results of determinations done on the feces are tabulated. From the lack of change in the fat content (Column 10) it is clear that vanadium did not interfere with fat absorption from the gastrointestinal tract. In Figure 3 the mean 24 hour fecal content of the various sterol fractions and the bile acids are graphed separately and as total sterol excretion. The top curve shows the decline in total fecal sterol excretion $(p<0.05)$ during the period of vanadium administration and then the rise $(p<0.05)$ during the recovery phase after vanadium. The total L. B. positive sterols as determined by the 
Abell, Levy, Brodie and Kendall procedure (17) and the digitonin precipitable, L. B. negative sterols declined significantly during vanadium dosage but the decrease in the bile acids was not significant when considered separately.

\section{Relation of absorbed vanadium to effects on sterol balance}

It is known that urinary vanadium represents approximately 60 per cent of the vanadium absorbed from the gastrointestinal tract during the previous 24 hours (26). Urinary vanadium levels as determined weekly by a dye method (13) showed a wide variation both from one week to the next for the same individual and from one subject to another on the same dosage of diammonium oxy-tartratovanadate. These values ranged from 4 to $100 \mu \mathrm{g}$. V/L. urine. It soon became obvious that the absorption of vanadium from the gastrointestinal tract was most variable. However, at the conclusion of the vanadium administration period, total urine was collected for the next five days and analyzed for vanadium content by a chemical and a spectrographic method. This vanadium represented that which had been absorbed and retained in the body. In Figure 4 the residual vanadium has been plotted against the per cent reduction in the serum free cholesterol for each of the men in the study. It is clear that a relationship exists between the retained vanadium and the lowering of the serum free cholesterol. In Figure 5, using the spectrographic data, we find a similar curve which suggests that a concentration of approximately $1 \mu \mathrm{g}$. vanadium per pound body weight is necessary for a maximal effect.

\section{Vanadium toxicity}

There were no overt evidences of toxicity from vanadium in any of the men. Complete blood counts including platelets, routine urinalyses, blood urea nitrogen and blood glucose remained unchanged during the six weeks of vanadium administration. Liver functions as determined by serum cholesterol esters, serum alkaline phosphatase, serum transaminase and serum bilirubin were unchanged. The possibility existed that inhibition of cholesterol synthesis might also

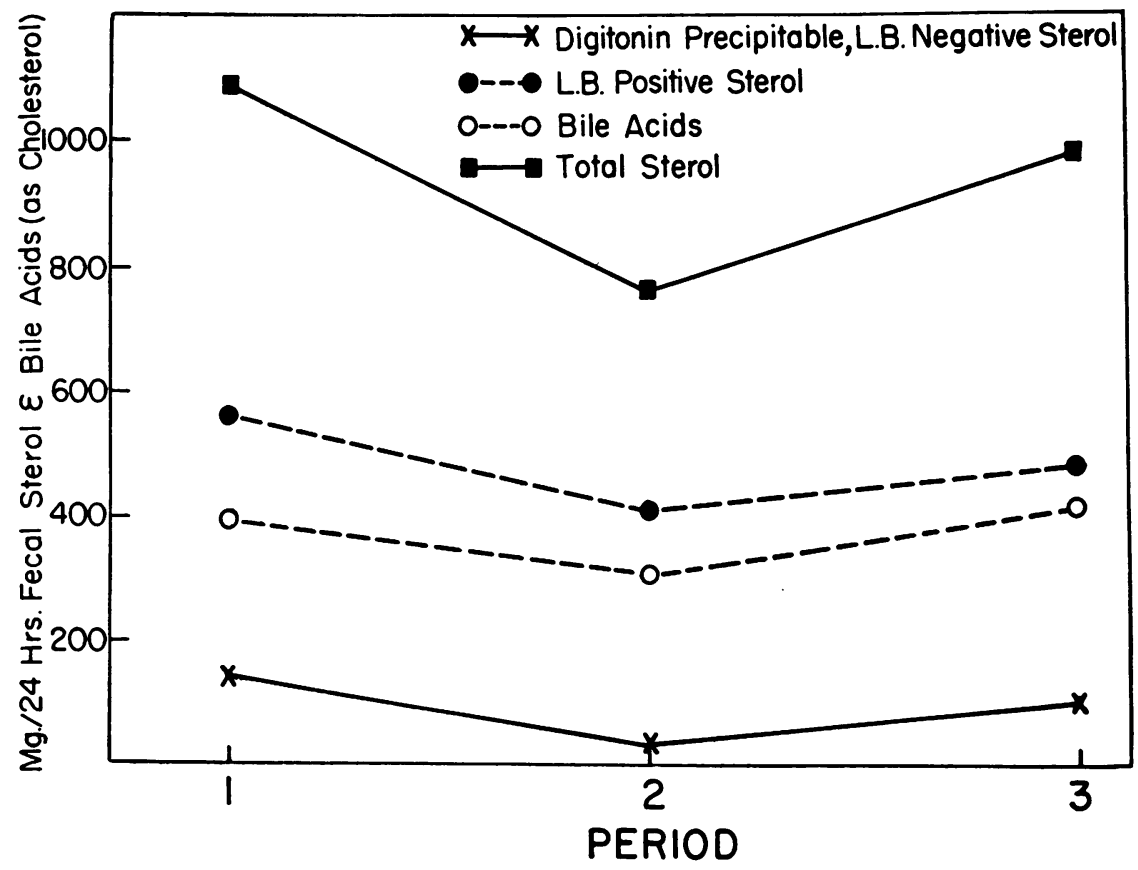

Fig. 3. Changes in Mean Fecal Sterol and Bile Acid Excretion Induced by Inhibition of Endogenous Cholesterol Synthesis

$1=$ end of control period; $2=$ end of vanadium period; $3=$ end of recovery period. 


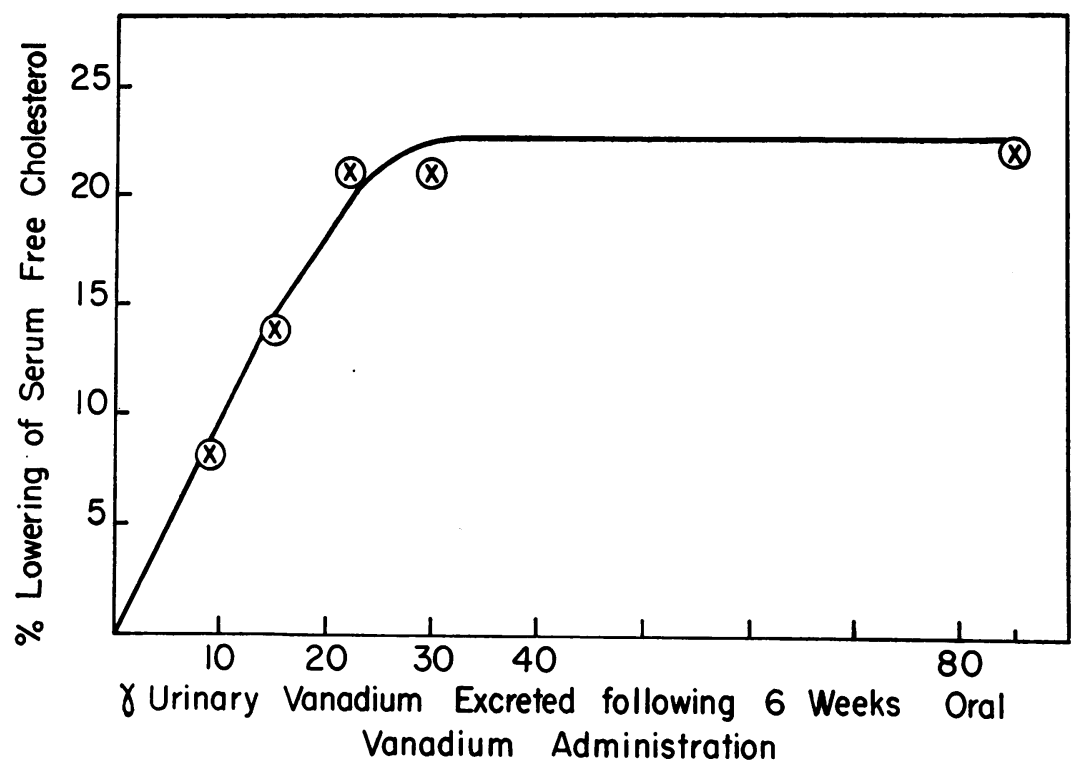

Fig. 4. Relationship Between Fall in Serum Free Cholesterol and Retained Vanadium

inhibit adrenal corticoid production, but 24 hour urinary 17-ketosteroid and 17,21-dihydroxy-20ketosteroid excretions were not lowered by the six weeks of vanadium administration. Thus no evidence of measurable toxic effect of vanadium on bone marrow, liver, kidney or adrenal was found during this short-term study.
DISCUSSION

From the data presented in this paper, the reader may have derived the following impressions: 1) The reduction in serum cholesterol is minimal; 2) no direct evidence for endogenous cholesterol synthesis inhibition is provided; and

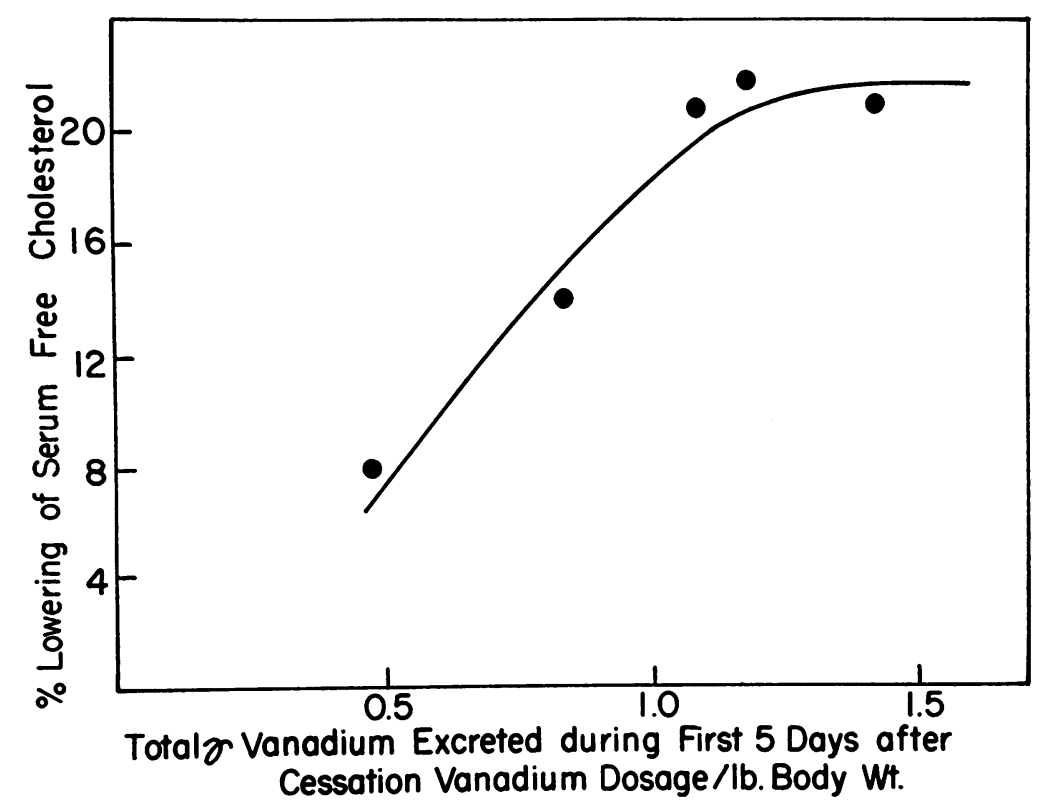

Fig. 5. Relationship Between Lowering of Serum Free Cholesterol and Retained Vanadium per Pound of Body Weight 
3 ) the reduction in fecal sterol output is subject to a variety of interpretations.

In discussing the first of these points, it is clear that the reduction in serum cholesterol after six weeks of vanadium administration is small; the maximal reduction in free cholesterol is about 20 per cent. However, it must be noted that the subjects of this study were normocholesteremic young men with presumably normal rates of cholesterol synthesis and with normal plasma lipoprotein transport systems. Under such conditions it seems unwarranted to expect a marked change in serum cholesterol after a short period of inhibition of endogenous cholesterol synthesis.

The second point, concerning evidence for cholesterol synthesis inhibition, must be approached indirectly if one is to avoid the use of radioactive tracers in normal humans. Vanadium has been shown to inhibit cholesterol synthesis in animals by direct means $(3,4)$. To qualify as potentially effective in man, an inhibitor of cholesterol synthesis must be shown to block one of the steps between acetoacetate and squalene in the synthetic sequence of cholesterol and further, the inhibition of human tissue cholesterol synthesis must be demonstrated (1). Vanadium as diammonium oxy-tartratovanadate, has been reported to fulfill these criteria $(2,27)$.

The reduction in fecal sterol output may be interpreted in three ways: 1) It may represent no change in endogenous cholesterol synthesis with an actual retention of cholesterol in the tissues and an equivalent reduction in fecal output;2) it may represent a reduction in endogenous cholesterol synthesis with a corresponding lowering of fecal sterol excretion but with no net change in tissue sterol content; and 3) it may represent a reduction in endogenous cholesterol synthesis with a depletion of tissue sterol stores as well as the reduction in fecal sterol output.

It is impossible to choose between these alternatives on the basis of the data presented in the paper. However, it is possible to furnish indirect evidence which makes the first possibility most unlikely and to suggest a mathematical means of differentiating between the second and third alternatives.

Let us first consider the possibility that tissue sterol stores have actually increased during the period of vanadium administration with no change in cholesterol synthesis. The evidence that cholesterol synthesis is inhibited has been given. Mountain, Stockell and Stokinger found lowered tissue sterol stores after vanadium administration in normocholesteremic rabbits (5). Such direct data for man are not available. However, suggestive evidence is provided by cholesterol analyses of livers from two patients with brain tumors who had received diammonium oxy-tartratovanadate for four and eight months, respectively. The liver cholesterol levels were 225 and $250 \mathrm{mg}$. per 100 $\mathrm{Gm}$. of liver, values below the average normal of $300 \mathrm{mg}$. per $100 \mathrm{Gm}$. for a $70 \mathrm{Kg}$. man (28).

To enable us to choose between the possibilities that tissue sterol stores have remained the same or decreased, we must discuss the validity of our balance methods and the procedure for calculating the tissue sterol stores from the balance data.

In order to evaluate the effect of a cholesterol synthesis inhibitor on sterol balance in man under rigid dietary control, it is necessary to measure the dietary sterol, the fecal neutral sterol and the fecal bile acids. Then, assuming the amounts of sterols lost by excretion in urine to be insignificant and those lost in sebum to be constant and knowing in this case that conversion to steroid hormones is unchanged, the sterol balance may be determined by the calculations given in the Methods. These calculations were devised as a means of separating the effect of a drug on the serum cholesterol level from its effect on the tissue sterol level. It has been apparent to clinicians for years that in any given patient the level of the serum cholesterol is a poor means of judging the degree of atherosclerosis. By the same token, perhaps we should be more reserved in using a fall in serum cholesterol after a particular type of therapy as an indication of a beneficial action. By analogy one is reminded of the frequent lack of correlation between serum and tissue potassium levels.

\section{Validity of the calculations}

The initial validity of the calculations depends on whether the lowering of total fecal sterol output after vanadium is due to increased destruction of sterol by the bacterial flora of the intestinal tract. To solve this problem, feces with and without added vanadium were incubated and then analyzed. No change in total fecal sterol content was found. 
TABLE II

Calculated changes in body and tissue sterol content* during vanadium administration

\begin{tabular}{|c|c|c|c|c|c|c|c|c|c|c|c|c|c|}
\hline \multirow[b]{3}{*}{ Subject } & \multirow{3}{*}{$\begin{array}{l}\text { Recovery } \\
\text { period, } \\
\text { SR }\end{array}$} & \multicolumn{12}{|c|}{ Week of vanadium dosage } \\
\hline & & \multicolumn{4}{|c|}{2} & \multicolumn{4}{|c|}{4} & \multicolumn{4}{|c|}{6} \\
\hline & & $\mathrm{Sv}$ & $\Delta \mathrm{Se}$ & $\Delta \mathrm{B}$ & $\Delta \mathrm{T}$ & $\mathrm{Sv}$ & $\Delta \mathrm{Se}$ & $\Delta \mathrm{B}$ & $\Delta \mathrm{T}$ & $\mathrm{Sv}$ & $\Delta \mathrm{Se}$ & $\Delta \mathrm{B}$ & $\Delta \mathrm{T}$ \\
\hline $\begin{array}{l}\text { B. B. } \\
\text { W. B. } \\
\text { R. M. } \\
\text { D. S. } \\
\text { E. W. }\end{array}$ & $\begin{array}{l}545 \\
356 \\
107 \\
135 \\
645\end{array}$ & $\begin{array}{r}465 \\
239 \\
34 \\
155 \\
391\end{array}$ & $\begin{array}{r}+7 \\
+3 \\
+16 \\
+11 \\
-4\end{array}$ & $\begin{array}{r}-11 \\
-21 \\
+88 \\
+31 \\
-\quad 2\end{array}$ & $\begin{array}{l}-18 \\
-24 \\
+72 \\
+20 \\
+\quad 2\end{array}$ & $\begin{array}{r}513 \\
189 \\
40 \\
90 \\
711\end{array}$ & $\begin{array}{r}+5 \\
+8 \\
+14 \\
+21 \\
-9\end{array}$ & $\begin{array}{l}+35 \\
-57 \\
+59 \\
-21 \\
-27\end{array}$ & $\begin{array}{l}+30 \\
-65 \\
+45 \\
-42 \\
-18\end{array}$ & $\begin{array}{r}520 \\
240 \\
105 \\
65 \\
457\end{array}$ & $\begin{array}{l}-3 \\
-31 \\
-52 \\
-31 \\
-36\end{array}$ & $\begin{array}{l}-30 \\
-90 \\
-15 \\
-71 \\
-39\end{array}$ & $\begin{array}{l}-27 \\
-59 \\
+37 \\
-40 \\
-3\end{array}$ \\
\hline
\end{tabular}

${ }^{*}$ Expressed as $\mathrm{mg}$. cholesterol per day; $\mathrm{S}=$ synthesis; $\Delta \mathrm{Se}=$ change in total serum cholesterol content; $\Delta \mathrm{B}=$ change in total body sterol content; and $\Delta \mathrm{T}=$ change in total tissue sterol content.

Without the use of isotopes it was, of course, impossible to assay directly the amount of absorbed dietary sterol. By the method of Cook, Edwards and Riddell (21) the increment in sterol absorption over that existing in the control period is measured. Thus our calculated amounts of ${ }^{\mathrm{A}} \mathrm{D}_{\mathrm{R}}$ and ${ }^{A} \mathrm{D}_{\mathrm{V}}$ are each too small by the quantity of dietary sterol absorbed in the control period. However, as can be seen from the example in the Addendum, even if this missing quantity were as high as $400 \mathrm{mg}$. (representing an unlikely 60 per cent absorption in the control period) the change in the $I_{V} / I_{R}$ ratio would be only 2 per cent. Also, any increase in ${ }^{A F} D_{V}$ would increase the significance of the negative change in $\Delta \mathrm{B}$.

To calculate the synthesis during the recovery period, it is necessary to assume that the steady state has again been reached and that $\Delta B_{R}$ is zero. Because it is likely that, in the absence of a lowering of cholesterol endogenous synthesis, man is always storing some cholesterol, in actuality $\Delta \mathrm{B}_{\mathbf{R}}$ is probably a very small positive number. However, this constant storage of sterol must be so small on a daily basis that our assumption that it is zero should not influence the far larger changes found in sterol output.

Finally, to calculate the synthesis in the vanadium periods, it is necessary to assume that the ratio $I_{V} / I_{R}$ is proportional to the ratio $S_{V} / S_{R}$. This assumption is justified because $S$ is the major component of $I$ and because the reduction in synthesis after vanadium so calculated is always less than might be expected from direct isotopic measurements of synthesis depression in animal and human tissues in in vivo experiments $(4,27)$ under similar conditions of vanadium dosage.

It is likely, therefore, that these calculations ex- press the minimal reduction in tissue sterol content which has occurred, because the period of greatest change (i.e., from the control to the vanadium periods) is not used and because the calculated rate of synthesis inhibition is minimal. It must be stressed that, due to the nature of the assumptions relating to the steady state during and after vanadium, the values calculated for the various entities cannot be regarded as absolute amounts. Further, it is clear that ${ }^{\mathrm{A}} \mathrm{D}$ and ${ }^{\mathrm{AF}} \mathrm{D}$ can be more exactly estimated by methods more elegant than those available for this study. However, in the opinion of the authors, the logical basis of the calculations is sound and accordingly the trend shown by $\Delta \mathrm{B}$ and $\Delta \mathrm{T}$ is correct.

Despite the factors which tend to minimize the calculated effects of cholesterol synthesis inhibition, it can be seen from Table II that in all the five men receiving vanadium for six weeks a reduction in body sterol content $\left(\Delta \mathrm{B}_{\mathrm{V}}\right)$ occurred. The importance of the concept of calculating the change in tissue sterol content $(\Delta \mathrm{T})$ becomes clear when one notes that all the men showed a reduction in total serum cholesterol $(\Delta \mathrm{Se})$ whereas only four men actually were lowering their tissue sterol stores $(\Delta \mathrm{T})$. For example, if one judged the results of vanadium on the basis of lowering of serum cholesterol alone he would think that R. M. showed the greatest effect, while in actuality R. M. was still depositing sterol in his tissues.

The trend of $\Delta \mathrm{B}$ and $\Delta \mathrm{T}$ during the period of vanadium administration shows the progressive effect of cholesterol synthesis inhibition. The mean figures for the five men are presented graphically in Figure 6 . Both $\Delta \mathrm{B}$ and $\Delta \mathrm{T}$ have remained positive until Week 2 . By Week 6 both $\Delta \mathrm{B}$ and $\Delta \mathrm{T}$ have become negative. It should 


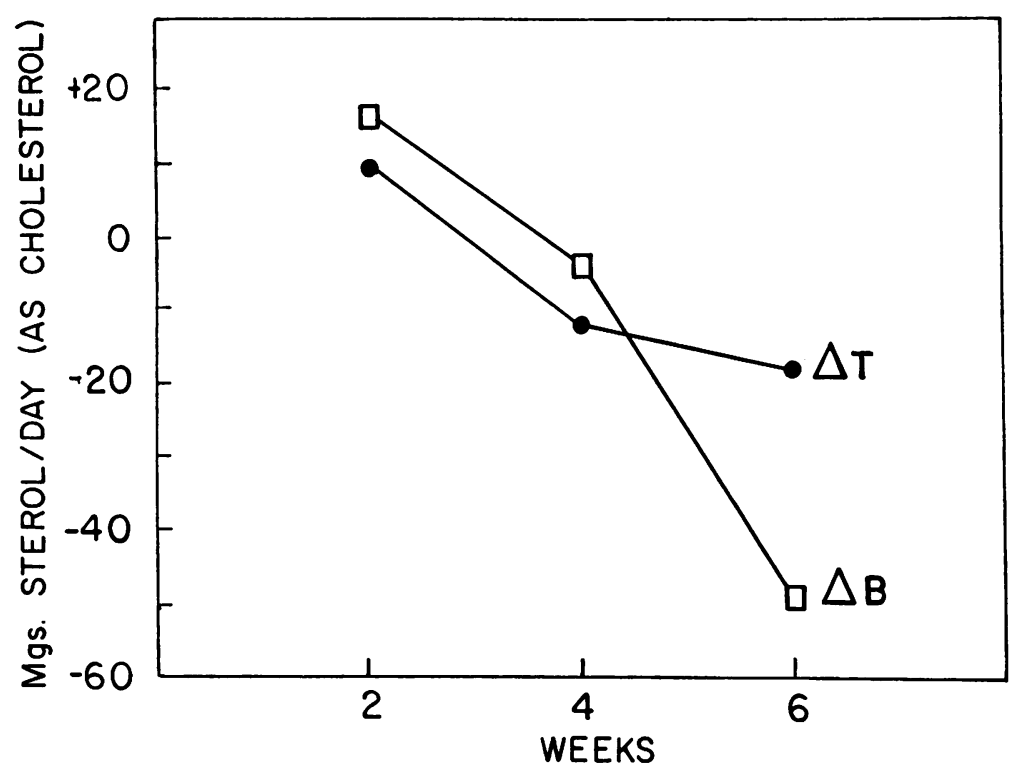

Fig. 6. Trend of Mean $\Delta B$ and Mean $\Delta$ T During Vanadium Administration

$\Delta \mathrm{B}=$ body sterol content in given week of vanadium period minus body sterol content in recovery period; $\Delta \mathrm{T}=$ tissue sterol content in given week of vanadium period minus tissue sterol content in recovery period.

be noted again that the fall in $\Delta \mathrm{B}$ is more dramatic, emphasizing the influence of the relatively labile serum cholesterol. However, the lesser decrease in $\Delta \mathrm{T}$ is progressive and the decline from Week 2 to Week 6 is statistically significant at the $<0.05$ level.

London and Rittenberg, using $\mathrm{D}_{2} \mathrm{O}$, calculated the amount of serum cholesterol synthesized per day by a normal young man to be $546 \mathrm{mg}$. (29). More recently, Taylor, Cox, Davis and Cross have measured directly the synthesis of cholesterol from acetate in several hundred human livers (30). Our mean of $450 \mathrm{mg}$. of cholesterol synthesized per 24 hours [this quantity includes measured urinary corticoids and an estimated skin sterol synthesis per 24 hours of $75 \mathrm{mg}$. (28) at the end of the recovery period (Table II)] is roughly four times their mean obtained on patients undergoing surgery. However, allowing for the nutritional differences involved and the fact that they measure only hepatic cholesterol synthesis, our calculated amounts of total body synthesis tend to support Taylor and co-workers' contention that the true human cholesterol synthesis rate may be far lower than currently accepted estimates.
Throughout this study it has been assumed that the effects measured were attributable to the action of vanadium as an inhibitor of cholesterol synthesis alone. While there is no doubt that the major effect of vanadium on lipids is its inhibition of cholesterol synthesis, inhibition of lipogenesis in vitro (3) and of phospholipid synthesis in vitro and in vivo have been reported (25).

Thus, from the data in this paper it can be reasonably concluded that through inhibition of endogenous cholesterol synthesis by a specific inhibitor of that process it is possible to produce a lowering of tissue cholesterol stores. With specific inhibitors of cholesterol synthesis a practical means is available to test the widely held hypothesis that reduction of body cholesterol content may modify the course of atherosclerosis and, in particular, coronary atherosclerosis. Such tests would require long term studies on large numbers of individuals. The effect of reduction of body cholesterol stores could then be determined from the incidence of myocardial infarction and survival of the treated group. In this manner a definitive answer to the correctness of the original hypothesis can finally be obtained. 


\section{SUMMARY}

1. The effect of a cholesterol synthesis inhibitor (vanadium) on sterol balance in five young men on a fixed diet has been studied.

2. Inhibition of endogenous cholesterol synthesis in man for six weeks resulted in a statistically significant lowering of the serum total and free cholesterol levels and of the $\mathrm{C} / \mathrm{P}$ ratio. Concomitantly there was a significant reduction in fecal total sterol excretion.

3. A method is presented for the calculation of the dynamics of tissue sterol storage from sterol balance data. By this means it is shown that inhibition of endogenous cholesterol synthesis produced a lowering of tissue cholesterol stores in four of the five men studied.

\section{ACKNOWLEDGMENTS}

The authors wish to express their graditude to Dr. R. P. Cook of St. Andrews University, Dundee, Scotland and Dr. H. J. Grady of the University of Kansas for their aid in reviewing the calculations. Without the helpful advice and competent supervision of Mrs. Jack McCabria, the necessary rigidity of the diets could not have been maintained. The authors are likewise indebted to Misses Patricia Unangst and Mary Ruth Dietrich for valuable technical assistance.

\section{ADDENDUM}

Sample calculation for B. B., sixth week of vanadium period, from data in Table I

1. ${ }^{A} D=$ neutral sterol fecal content of control period minus neutral sterol fecal content of experimental period (21).

$$
\begin{aligned}
& { }^{A} D_{R}=(676+152)-(606+56)=166 \mathrm{mg} \cdot \text { per day. } \\
& { }^{A} D_{\mathrm{v}}=(676+152)-(510+40)=278 \mathrm{mg} \text {. per day. } \\
& { }^{A F D}=0.25 \times{ }^{A D}(22) \text {. } \\
& { }^{A}{ }^{F} D_{R}=0.25 \times 166=42 \mathrm{mg} \text {. per day. } \\
& { }^{A F} D_{V}=0.25 \times 278=70 \mathrm{mg} \text {. per day. } \\
& 740-{ }^{\wedge} \mathrm{D}+\mathrm{I}=\text { gut sterol output. } \\
& I_{R}=(606+56+499+166-740)=587 \mathrm{mg} \text {. per } \\
& \text { day. } \\
& \mathrm{IV}_{\mathrm{V}}=(510+40+472+278-740)=560 \mathrm{mg} \text {. per } \\
& \text { day. } \\
& \text { 2. } I_{R}=S_{R}+{ }^{A F} D_{R}+\Delta B_{R} \text {, where } \Delta B_{R}=0 ; S_{R}=
\end{aligned}
$$

4. $I_{v}=S_{v}+A^{F} D_{v}+\Delta B_{v} ; \Delta B_{v}=560-520-70$

$=-30 \mathrm{mg}$. per day.

5. To calculate $\Delta \mathrm{Sev}_{\mathrm{v}}$ :

$$
\begin{aligned}
\mathrm{Se}_{\mathrm{R}}= & 1,410 \times \frac{146}{2.2} \times 0.05=4,681 \mathrm{mg} . \text { in total serum } \\
\text { at end of recovery period; } & \\
\mathrm{Se}_{\mathrm{v}}= & 1,380 \times \frac{147}{2.2} \times 0.05=4,610 \mathrm{mg} . \text { in total serum } \\
\text { at end of vanadium period; and } & \\
\Delta \mathrm{Se}_{\mathrm{V}}= & \frac{4,610-4,681}{21}=-3 \mathrm{mg} . \text { per day. }
\end{aligned}
$$

6. $\Delta \mathrm{B}=\Delta \mathrm{T}+\Delta \mathrm{Se} ; \Delta \mathrm{T}_{\mathrm{v}}=-30-(-3)=-27 \mathrm{mg}$. per day.

\section{REFERENCES}

1. Curran, G. L., and Azarnoff, D. L. Inhibition of cholesterol biosynthesis in man. A. M. A. Arch. intern. Med. 1958, 101, 685.

2. Azarnoff, D. L., and Curran, G. L. Site of vanadium inhibition of cholesterol biosynthesis. J. Amer. chem. Soc. 1957, 79, 2968.

3. Curran, G. L. Effect of certain transition group elements on hepatic synthesis of cholesterol in the rat. J. biol. Chem. 1954, 210, 765.

4. Curran, G. L., and Costello, R. L. Reduction of excess cholesterol in the rabbit aorta by inhibition of endogenous cholesterol synthesis. J. exp. Med. 1956, 103, 49.

5. Mountain, J. T., Stockell, F. R., Jr., and Stokinger, H. E. Effect of ingested vanadium on cholesterol and phospholipid metabolism in the rabbit. Proc. Soc. exp. Biol. (N. Y.) 1956, 92, 582.

6. Eades, C. H., Jr., and Gallo, D. G. Effect of vanadyl sulfate on plasma and tissue cholesterol levels and atherosclerosis in the chicken. Fed. Proc. 1957, $16,176$.

7. Sperry, W. M., and Webb, M. A revision of the Schoenheimer-Sperry method for cholesterol determination. J. biol. Chem. 1950, 187, 97.

8. Fiske, C. H., and Subbarow, Y. The colorimetric determination of phosphorus. J. biol. Chem. 1925, $66,375$.

9. Gomori, G. A modification of the colorimetric phosphorus determination for use with the photoelectric colorimeter. J. Lab. clin. Med. 1941-42, 27, 955.

10. Bragdon, J. H. Colorimetric determination of blood lipides. J. biol. Chem. 1951, 190, 513.

11. Kind, P. R. N., and King, E. J. Estimation of plasma phosphatase by determination of hydrolyzed phenol with aminoantipyrine. J. clin. Path. 1954, 7, 322.

12. Steinberg, D., Baldwin, D., and Ostrow, B. H. A clinical method for assay of serum glutamic-oxalacetic transaminase. J. Lab. clin. Med. 1956, 48, 144.

13. Rockhold, W. T., and Talvitie, N. A. Vanadium concentration of urine. Rapid colorimetric method for its estimation. Clin. Chem. 1956, 2, 188. 
14. Drekter, I. J., Pearson, S., Bartczak, E., and McGavack, T. H. A rapid method for the determination of total urinary 17-ketosteroids. J. clin. Endocr. 1947, 7, 795.

15. Silber, R. H., and Porter, C. C. The determination of 17, 21-dihydroxy-20-ketosteroids in urine and plasma. J. biol. Chem. 1954, 210, 923.

16. Costello, R. L., and Curran, G. L. Modified turbidimetric procedure for determination of cholesterol. Amer. J. clin. Path. 1957, 27, 108.

17. Abell, L. L., Levy, B., Brodie, B. B., and Kendall, F. E. A simplified method for the estimation of total cholesterol in serum and demonstration of its specificity. J. biol. Chem. 1952, 195, 357.

18. Idler, D. R., and Baumann, C. A. Skin sterols. III. Sterol structure and the Liebermann-Burchard reaction. J. biol. Chem. 1953, 203, 389.

19. Lewis, B. Determination of faecal bile acids. S. Afr. J. Lab. clin. Med. 1957, 3, 316.

20. Sperry, W. M., and Brand, F. C. The determination of total lipides in blood serum. J. biol. Chem. 1955, 213, 69.

21. Cook, R. P., Edwards, D. C., and Riddell, C. Cholesterol metabolism. 7. Cholesterol absorption and excretion in man. Biochem. J. 1956, 62, 225.

22. Siperstein, M. D., and Murray, A. W. Cholesterol metabolism in man. J. clin. Invest. 1955, 34, 1449.
23. Gould, R. G., LeRoy, G. V., Okita, G. T., Kabara, J. J., Keegan, P., and Bergenstal, D. M. The use of $\mathrm{C}^{14}$-labeled acetate to study cholesterol metabolism in man. J. Lab. clin. Med. 1955, 46, 372.

24. Humphrey, D. C. The causes of coronary heart disease. Guy's Hosp. Rep. 1957, 106, 101.

25. Snyder, F., and Cornatzer, W. E. Vanadium inhibition of phospholipid synthesis and sulphydryl activity in rat liver. Nature (Lond.) 1958, 182, 462.

26. Talvitie, N. A., and Wagner, W. D. Studies in vanadium toxicology. II. Distribution and excretion of vanadium in animals. Arch. industr. Hyg. 1954, 9, 414.

27. Azarnoff, D. L., Curran, G. L., and Williamson, W. P. Incorporation of acetate- $1-\mathrm{C}^{\mathbf{1 4}}$ into cholesterol by human intracranial tumors in vitro. J. nat. Cancer Inst. 1958, 21, 1109.

28. Cook, R. P. Cholesterol. New York, Academic Press Inc., 1958, p. 174.

29. London, I. M., and Rittenberg, D. Deuterium studies in normal man. I. The rate of synthesis of serum cholesterol. II. Measurement of total body water and water absorption. J. biol. Chem. 1950, 184, 687.

30. Taylor, C. B., Cox, G. E., Davis, C. B., Jr., and Cross, S. L. Cholesterol synthesis in human liver. Fed. Proc. 1958, 17, 459. 